\title{
UNG THU' BIẺU MÔ TUYÉN ĐẠI TRỰC TRÀNG TRÊN BỆNH NHÂN CÓ HỘI CHỨNG PEUTZ - JEGHER: BÁO CÁO CA BẸNH VÀ HÒI CỨU Y VĂN
}

\author{
Trần Thị Hoa ${ }^{1, \bowtie}$, Đào Thị Luận ${ }^{1,2}$, Trần Ngọc Dũng², \\ Nguyễn Thị Quỳnh ${ }^{1}$
}

${ }^{1}$ Bộ môn Giải phẫu bệnh, Trường Đại học Y Hà Nội ${ }^{2}$ Khoa Giải phẫu bệnh, Bệnh viện Đại học Y Hà Nội

Hội chứng Peutz-Jeghers là một hội chứng hiếm, được đặc trưng bởi sự xuất hiện của các polyp dạng harmartoma ở đường tiêu hoá và các đốm tàn nhang mọc rất đặc trưng quanh môi, trong miệng, ở tay, chân và mi mắt. Mục tiêu của nghiên cứu nhằm mô tả ca bệnh ung thư biểu mô tuyến đại trực tràng có hội chứng Peutz-Jeghers. Thiết kế nghiên cứu mô tả ca bệnh. Bệnh nhân nam, 36 tuổi, có tiền sử mắc hội chứng PeutzJeghers, nôn nhiều, đau quặn bụng từng cơn. Chẩn đoán hình ảnh cho thấy khối lồng ruột non vùng tiểu khung, đa polyp đại trực tràng, đặc biệt đoạn trực tràng cao có polyp lớn kích thước 38 x $37 \mathrm{~mm}$, dạng nụ sùi, thuỳ múi. Kết quả mô bệnh học cho thấy: polyp lớn ở trực tràng là ung thư biểu mô tuyến xâm nhập lớp cơ trơn; các polyp khác là polyp Peutz - Jeghers điển hình, có kèm loạn sản độ thấp. Bệnh nhân được chẩn đoán là ung thư biểu mô tuyến biệt hóa vừa xâm lấn cơ trực tràng trên bệnh nhân có hội chứng Peutz - Jeghers.

Từ khóa: Hội chứng Peutz-Jeghers, ung thư biểu mô tuyến đại trực tràng.

\section{I. ĐẠT VẤN ĐỀ}

Hội chứng Peutz-Jeghers là một hội chứng hiếm gặp, lần đầu tiên được mô tả bởi bác sĩ nhi khoa Jan Peutz vào năm 1921 trong một gia đình với các thành viên có các đốm sắc tố da và nhiều polyp ở ruột non. Các ca bệnh tương tự cũng được báo cáo ở Hoa Kì bởi Jeghers và cs (1949), do đó bệnh này được đặt tên là hội chứng Peutz-Jeghers (PJS). ${ }^{1}$ PJS là một bệnh di truyền do đột biến trong gen STK11 (còn được gọi là LKB1) ở nhiễm sắc thể số $19 .{ }^{1}$ PJS gặp ở cả hai giới với tỷ lệ ngang nhau, đặc trưng bởi sự xuất hiện của các đốm sắc tố trong niêm mạc má ở $90 \%$ số trường hợp và nhiều polyp hamartoma đường tiêu hoá (thường dưới 20 polyp) $)^{1,2}$ Các đốm sắc tố là sự biểu hiện

Tác giả liên hệ: Trần Thị Hoa

Bệnh viện Đại học Y Hà Nội

Email: tranthihoa17yek110hmu@gmail.com

Ngày nhận: 19/09/2021

Ngày được chấp nhận: 22/10/2021 sớm nhất của PJS, điển hình xuất hiện ngay trong năm đầu đời. Các polyp hầu hết ở hỗng tràng, đôi khi ở hồi tràng, dạ dày, tá tràng và đại tràng. Những polyp này xuất hiện từ thời thơ ấu và thường dẫn đến lồng ruột hay xuất huyết tiêu hoá. ${ }^{1}$

Nguy cơ mắc các khối u ác tính đường tiêu hoá và ngoài đường tiêu hoá tăng lên đáng kể ở bệnh nhân PJS. Nguy cơ tử vong do ung thư đường tiêu hoá ở những bệnh nhân này cao hơn gấp 13 lần so với ở nhóm dân số chung, nguy cơ mắc bất kì bệnh ác tính nào khác (đặc biệt là ung thư cơ quan sinh dục, vú, tuy và phổi) cũng cao gấp 9 lần. ${ }^{2}$ Trong bài báo này, chúng tôi báo cáo một trường hợp hội chứng Peutz-Jeghers có ung thư biểu mô tuyến trực tràng ở bệnh nhân nam, 36 tuổi, với mục tiêu: Nhận xét một số đặc điểm lâm sàng và giải phẫu bệnh của hội chứng Peutz-Jeghers và hồi cứu y văn. 


\section{BÁO CÁO CA LÂM SÀNG}

\section{Bệnh cảnh lâm sàng}

Bệnh nhân nam giới, 36 tuổi, có tiền sử mắc hội chứng Peutz-Jeghers biểu hiện đa polyp dạ dày, ruột non, đại trực tràng (đã mổ bụng 4 lần vì khối lồng ruột non), xuất huyết tiêu hoá thấp, vào Bệnh viện Đại học $Y$ Hà Nội vì nôn nhiều, đau quặn bụng từng cơn. Bệnh nhân không sốt, thể trạng gầy $(B M I=18)$, huyết áp 130/90 $\mathrm{mmHg}$, mạch 90 lần/phút. Tổng phân tích tế bào máu toàn phần: có tình trạng thiếu máu (Số lượng hồng cầu 4,12 $(3,9$ - 5,4) T/l; huyết sắc tố 110 (125 - 145) g/L); hematocrit: 0,342. Quanh môi và mi mắt của bệnh nhân có các đốm tàn nhang rất đặc trưng.

\section{Chụp cắt lớp ổ bụng}

Hình ảnh khối lồng ruột non - ruột non vùng tiểu khung kích thước khoảng $61 \times 90 \mathrm{~mm}$, thành phần khối lồng là ruột non và mạch máu, mạc treo của nó; thành ruột và mạch máu còn ngấm thuốc đều sau tiêm; không rõ khối u bất thường bên trong; đa polyp trực tràng và có polyp lớn đoạn trực tràng cao kích thước 38 x 37 mm, dạng nụ sùi, thuỳ múi, sau tiêm ngấm thuốc; không có hạch lớn lân cận, không thâm nhiễm mỡ xung quanh. Sỏi túi mật. Lách to nhẹ. Giãn tĩnh mạch cửa.

\section{Chụp cộng hưởng từ tiểu khung}

Thành trực tràng có nhiều polyp lồi vào trong lòng trực tràng, polyp lớn nhất ở đoạn cao trực tràng kích thước 36 × 33 x 40 mm, bờ thuỳ múi, ranh giới không rõ với lớp cơ thành trực tràng, chưa thâm nhiễm mỡ mạc treo, chưa xâm lấn cơ quan lân cận. Vùng tiểu khung quan sát thấy một phần khối lồng ruột non, đường kính ngang $51 \mathrm{~mm}$, thành ruột ngấm thuốc đều sau tiêm. Vài hạch nhỏ tiểu khung.

\section{Nội soi ổ bụng và đường tiêu hóa}

Ổ bụng có ít dịch tiết, vòm hoành và phúc mạc tiểu khung nhã̃n, dạ dày và ruột non có nhiều polyp từ $0,5 \mathrm{~cm}$ đến $4,5 \mathrm{~cm}$. Có 4 khối lồng ở ruột non, khối lớn nhất do polyp ruột non tại miệng nối ruột cũ, cách góc hồi manh tràng $80 \mathrm{~cm}$. Ở trực tràng cao có khối lớn, kích thước lớn chiếm gần hết chu vi, chưa xâm lấn tạng lân cận. Có nhiều hạch nhỏ mềm dọc động mạch mạc treo tràng dưới.

\section{Chẩn đoán trước phẫu thuật}

Bệnh nhân được chẩn đoán trước phẫu thuật là nghi ngờ ung thư trực tràng cao/ hội chứng JPS. Bệnh nhân được chỉ định cắt đoạn đại trực tràng kèm vét hạch rộng rãi.

\section{Đại thể}

Đoạn đại trực tràng dài $22 \mathrm{~cm}$, cách diện cắt dưới $7 \mathrm{~cm}$ có $\mathrm{u}$ dạng sùi trên diện $4,5 \times 4 \mathrm{~cm}$, tổ chức xơ mỡ tương ứng mềm mại. Niêm mạc đại trực tràng có nhiều polyp từ 0,5 - 2 $\mathrm{cm}$. Các bệnh phẩm trên 10 polyp ruột non gửi rời không cuống, kích thước $0,5 \mathrm{~cm}$ đến 4,5 x 4 $\mathrm{cm}$, cắt qua xám dai.

\section{Vi thể}

Trực tràng có polyp lớn với hình ảnh vi thể là mô u gồm các tế bào có nhân lớn, bào tương hẹp, tỉ lệ nhân/ bào tương cao, chất nhiễm sắc thô, hạt nhân rõ, nhiều nhân chia không điển hình. Các tế bào u sắp xếp tạo cấu trúc tuyến không đều, xâm nhập tới lớp cơ, xâm lấn mạch bạch huyết. Bên cạnh đó, các polyp khác và polyp gửi kèm là ccas polyp PJG điển hình được cấu tạo từ các tuyến tăng kích thước với tế bào tuyến quá sản, có vùng loạn sản độ thấp; cơ niêm tăng sinh, chia nhánh phát triển về phía biểu mô; mô đệm xâm nhập viêm mạn tính. 

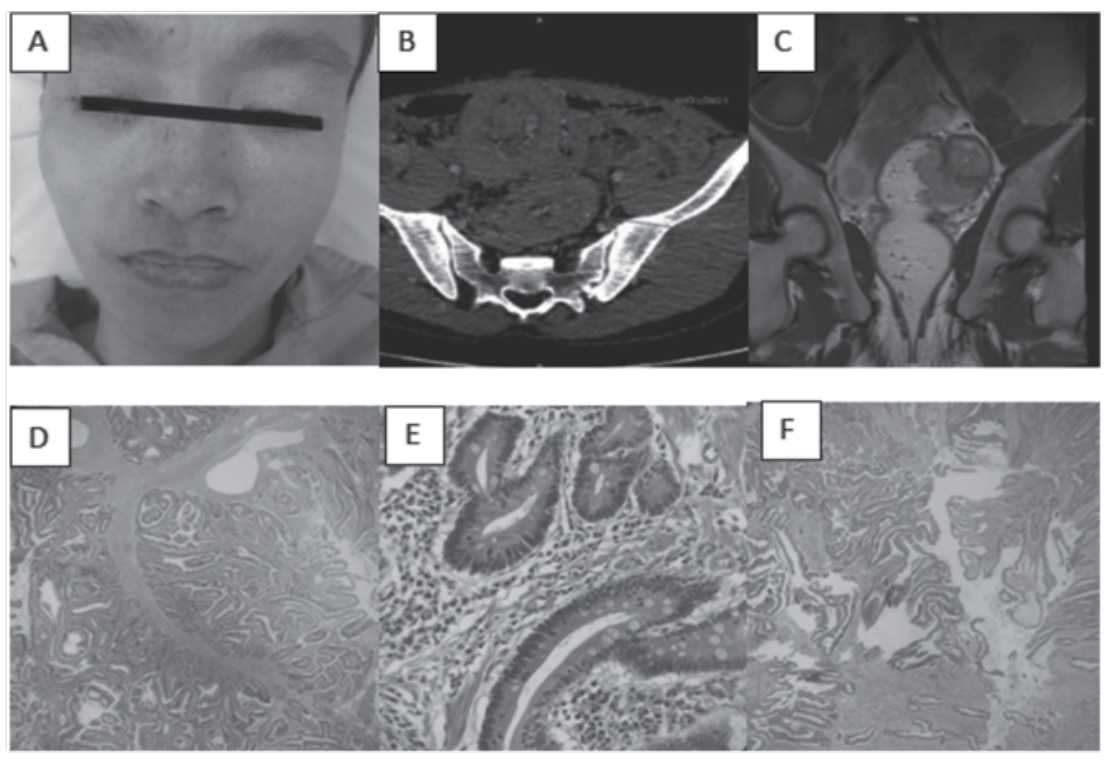

Hình 1. Các đặc điểm lâm sàng và cận lâm sàng

(A. Đốm sắc tố: Quanh mí mắt và niêm mạc môi của bệnh nhân; B. Hình ảnh chụp MSCT ổ bụng: Khối lồng ruột non - ruột non vùng tiểu khung kích thước khoảng $61 \times 90 \mathrm{~mm}$, thành phần khối lồng là ruột non và mạch máu, mạc treo của nó; C. Hình ảnh chụp cộng hưởng từ tiểu khung: Polyp đoạn cao trực tràng kích thước 36 x 33 x 40 mm, bờ thuỳ múi, ranh giới không rõ với lớp cơ thành trực tràng, chưa thâm nhiễm mớ mạc treo, chưa xâm lấn cơ quan lân cận; $\boldsymbol{D}$ và $\mathrm{F}$. Hình ảnh vi thể polyp ruột non: Polyp được cấu tạo từ các tuyến tăng kích thước với tế bào tuyến

\section{BÀN LUẬN}

Hội chứng Peutz-Jeghers hiếm gặp với tỉ lệ mắc từ $1 / 120.000$ tới $1 / 29.000 .^{3}$ Bệnh gặp ở cả hai giới với tỉ lệ ngang nhau, đặc trưng bởi các polyp Peutz-Jeghers đường tiêu hoá với các đốm tàn nhang quanh miệng, mi mắt, tay và chân (xảy ra trong hơn 95\% bệnh nhân). ${ }^{4}$ Bệnh thường khởi phát từ năm đầu tiên của cuộc đời với sự xuất hiện trước hết của các đốm sắc tố quanh mi mắt, niêm mạc môi, má và một số cơ quan khác (tay, chân). ${ }^{1}$ Thời điểm xuất hiện các triệu chứng đường tiêu hoá rất thay đổi (1 quá sản; cơ niêm tăng sinh, chia nhánh phát triển về phía biểu mô (D; HE, x 100), (F; HE, x 100); $E$. Hình ảnh vi thể khối u trực tràng cao: Mô u gồm các tế bào có nhân lớn, bào tương hẹp, tỉ lệ nhân/ bào tương cao, chất nhiễm sắc thô, hạt nhân rõ, nhiều nhân chia không điển hình; sắp xếp tạo cấu trúc tuyến không đều, xâm nhập tới lớp cơ, xâm lấn mạch bạch huyết (E; IHC, x400)

\section{Chẩn đoán mô bệnh học}

Ung thư biểu mô tuyến biệt hoá vừa, xâm lấn tới lớp cơ, xâm nhập mạch bạch huyết/ Polyp Peutz-Jeghers có loạn sản độ thấp (pT2NOMO).

- 40 tuổi), tuy nhiên, trước năm 10 tuổi, có tới $30 \%$ số bệnh nhân PJS đã trải qua phẫu thuật mở bụng. ${ }^{5,6}$ Bệnh nhân với đột biến gen STK 11 thường xuất hiện các triệu chứng ban đầu muộn hơn. Hầu hết các bệnh nhân có diễn biến lâm sàng đặc trưng của các đợt tái phát tắc ruột và chảy máu do polyp, bên cạnh đó, thường có triệu chứng rối loạn tiêu hóa (tiêu chảy, táo bón), chướng bụng, sụt cân (do hấp thu thức ăn kém). Gần một nửa số bệnh nhân trải qua hai hoặc nhiều ca mổ mở ổ bụng, dẫn đến một tỷ lệ khá 
lớn bệnh nhân bị hội chứng ruột ngắn do hậu quả của việc cắt bỏ ruột nhiều lần. ${ }^{1}$ Tiêu chuẩn để chẩn đoán PJS là khi có ít nhất 2 trong số các đặc điểm sau đây có thể được coi là có PJS: Ít nhất 2 u mô thừa dạng polyp loại Peutz-Jeghers trong ruột non, tàn nhang đặc trưng của miệng, môi, ngón tay hoặc ngón chân và ít nhất 1 người thân được chẩn đoán mắc PJS. Xét nghiệm di truyền được khuyến cáo cho những người thỏa mãn các tiêu chuẩn trên để tìm kiếm đột biến di truyền của gen STK11. Trường hợp của chúng tôi là bệnh nhân nam giới, 36 tuổi, có đủ tiêu chuẩn chẩn đoán hội chứng Peutz-Jeghers biểu hiện các đốm sắc tố quanh mắt và niêm mạc môi, đa polyp dạ dày, ruột non, đại trực tràng (đã mổ bụng 4 lần vì khối lồng ruột non), xuất huyết tiêu hoá thấp, vào Bệnh viện Đại học $Y$ Hà Nội vì nôn nhiều, đau quặn bụng từng cơn. Chẩn đoán hình ảnh thấy 4 khối lồng ở ruột non, kèm đa polyp trực tràng.

Các polyp nhìn thấy trong PJS có các đặc điểm mô học rất đặc trưng với thành phần biểu mô kéo dài giống như chiếc lá, các tuyến dãn rộng, kéo dài đến lớp dưới niêm mạc hoặc lớp cơ,và cơ trơn tăng sinh, chia nhánh phát triển về phía biểu mô. Những polyp này thường được gọi là polyp hamartoma, tuy nhiên, vẫn còn nhiều tranh luận xung quanh nguồn gốc của chúng. Mặc dù các polyp này trong đa số các trường hợp có hình ảnh mô học lành tính, ung thư biểu mô tuyến đường tiêu hóa có khả năng phát triển trên 2-3\% bệnh nhân bị ảnh hưởng bởi hội chứng PJS. ${ }^{4}$ Trong trường hợp này, bệnh nhân phát triển ung thư biểu mô tuyến đại trực tràng trên nền hội chứng PeutzJeghers biểu hiện đa polyp đường tiêu hoá.

Các nghiên cứu đã chỉ ra rằng, $\mathrm{PJS}$ là một hội chứng hầu hết do di truyền đột biến gen trội dòng mầm STK11 (còn được gọi là LKB1) trên nhiễm sắc thể 19p34 - p36, có thể do mắc phải đột biến mới xảy ra ngẫu nhiên. STK11 là một gen ức chế khối u, ngăn chặn các tế bào từ sự phát triển và phân chia quá nhanh một cách không kiểm soát. Đột biến trong gen này làm thay đổi cấu trúc hoặc chức năng của protein STK11, làm gián đoạn khả năng hạn chế sự phân chia tế bào của nó. Sự phát triển của tế bào không được kiểm soát dẫn đến sự hình thành các polyp không ung thư và khối $u$ ung thư ở những người mắc hội chứng PeutzJeghers. ${ }^{7}$ Mặt khác, không phải tất cả bệnh nhân PJS đều có đột biến gen này. Các đột biến của nhiễm sắc thể $6 q$ và 19q đã được phát hiện trong một số gia đình. ${ }^{8}$

Điều trị hội chứng PJS chủ yêu dùng phẫu thuật để cắt bỏ các polyp và phòng tránh ung thư hóa của các polyp này. Theo Hearle N. và cs (2006), 23\% bệnh nhân PJS sẽ phát triển ung thư trong tương lai và nguy cơ ung thư tăng nhanh sau tuổi 50 đối với tất cả các bệnh ung thư. ${ }^{9}$ Nguy cơ ung thư ruột non, dạ dày, tụy, đại tràng, thực quản, vú và buồng trứng là tương đối cao trong bệnh nhân PJS; nguy cơ mắc các bệnh ung thư này ở 30, 40, 50, 60 tuổi tương ứng là $1 \%, 9 \%, 15 \%$ và $33 \% .{ }^{10}$ Trường hợp của chúng tôi bệnh nhân đã được chẩn đoán JPS từ trước và được mổ 4 lần vì lồng ruột tại Bệnh viện Đại Học Y Hà Nội, nhưng do quá trình theo dõi kiểm tra định kỳ không được tuân thủ, khi có triệu chứng bệnh nhân mới tới khám, nên do đó khi nhập viện bệnh nhân đã có dấu hiệu của ung thư. Do đó, việc tầm soát bệnh nhân với hội chứng PJS là cần thiết nhằm hai mục đích: phát hiện sớm các ung thư biểu mô và ngăn ngừa các bệnh lý như chảy máu, thiếu máu, lồng ruột, tắc nghẽn bằng cách cắt bỏ các polyp lớn. Người bệnh được khuyến cáo nên nội soi đường tiêu hoá 3 năm một lần, bắt đầu từ tuổi 18 và kiểm tra vú bắt đầu từ tuổi 25 bằng siêu âm và chụp nhũ ảnh hàng năm sau tuổi $50 .{ }^{11}$ Tỷ lệ phát hiện đột biên gen STK11 từ 10\% - 94\% tùy thuộc vào phương pháp sàng lọc ở các trung 
tâm khác nhau; tuy nhiên phổ đột biến STK11 và mối tương quan kiểu gen - kiểu hình vẫn còn chưa được hiểu rõ. ${ }^{12}$ Theo nghiên cứu của Huyn-Dong Chae và cộng sự (2014) cho thấy mặc dù bệnh nhân bộc lộ đột biên gen STK11 dị hợp tử nhưng vẫn khỏe mạnh và không có triệu chứng PJS. ${ }^{13}$ Việc xác định đột biến gen STK 11 là rất có giá trị trong việc chẩn đoán PJS nhưng ít giá trị trong sàng lọc.

\section{KÉT LUẬN}

Đây là một trường hợp bệnh nhân nam, 36 tuổi, phát triển ung thư biểu mô tuyến trực tràng trên nền hội chứng Peutz-Jeghers biểu hiện đa polyp đường tiêu hoá. Đây là một tình trạng di truyền hiếm gặp, đặc trưng bởi sự phát triển các polyp hamartoma trong đường tiêu hóa (đặc biệt là dạ dày và ruột) và tăng nguy cơ phát triển một số loại ung thư. Do đó, người bệnh mắc hội chứng Peutz-Jeghers cần được tầm soát ung thư và theo dõi chặt chẽ để phát hiện sớm ung thư và điều trị kịp thời.

\section{TÀI LIẸU THAM KHẢO}

1. Islam M.R., Hossain M.S, Sheikh M.S., et al (2015). Peutz-Jeghers syndrome: a case report and literature review. Journal of Dhaka Medical College. 23(1).

2. Homan M., Dolenc Strazar, et al (2005). Peutz-Jeghers syndrome. A case report. Acta Dermatovenerol Alp Panonica Adriat. 14(1), 26-29.

3. Finan et al (1989). Gastrointestinal Polyposis Syndromes. Dermatologic Clinics. 7(3), 419-434.

4. Pereira C.M., Coletta R.D., Jorge J., et al (2005). Peutz-Jeghers syndrome in a 14-yearold boy: case report and review of the literature.
Int J Paediatr Dent. 15(3), 224-8.

5. Fernandez M.J., Martinez M.I., Fernandez J.R., et al (1995). Peutz-Jeghers syndrome in a neonate. J Pediatr. 126 (6), 965-7.

6. Hinds R., Philp C., Hyer W., et al (2004). Complications of childhood Peutz-Jeghers syndrome: implications for pediatric screening. J Pediatr Gastroenterol Nutr. 39 (2), 219-20.

7. Spigelman A.D., Thomson J.P. and Phillips R.K. (1990). Towards decreasing the relaparatomy rate in the Peutz-Jeghers syndrome: the role of preoperative small bowel endoscopy. Br J Surg. 77(3), 301-302.

8. Boardman L.A, Couch F.J, Burgart L.J, et al (2000). Genetic heterogeneity in Peutz-Jeghers syndrome. Hum Mutant 2000. 16, 23-30.

9. Hearle N., Schumacher V., Menko F.H., et al (2006). Frequency and spectrum of cancers in the Peutz-Jeghers syndrome. Clin Cancer Res. 12, 3209-3215.

10. Giardiello F.M., Brensinger J.D., Tersmette A.C., et al (2000). Very high risk of cancer in familial Peutz-Jeghers syndrome. Gastroenterology. 119, 1447-1453.

11. Beggs A.D., Latchford A.R., Vasen H.F., et al (2010). Peutz-Jeghers syndrome: a systematic review and recommendations for management. Gut. 59(7), 975-86.

12. McGarrity T.J., Amos C. (2006). PeutzJeghers syndrome: clinicopathology and molecular alterations. Cell. Mol. Life Sci. 63, 2135-2144.

13. Hyun-Dong Chae., Chang-Ho Jeon (2014. Peutx-Jeghers syndrome with germline mutation of STK11. Ann Surg Treat Res. 86(6), 325-330. 


\section{Summary \\ COLORECTAL ADENOMACARCINOMA IN A PATIENT WITH PEUTZ-JEGHERS SYNDROME}

Peutz-Jeghers Syndrome (PJS) is a rare disease, characterized by hamartomatous polyposis of the gastro-intestinal (GI) tract and pigmentation around lips, eyelids and macules on the buccal mucosa. The objective of the study was to describe one case of colorectal adenocarcinoma in a patient with Peutz-Jeghers Syndrome. A case study report was applied. A 36-year-old male with PJS was hospitalized because of vomiting and intermittent abdominal pain. Imaging showed smallbowel intussusception in the pelvic region, along with colorectal polyps; the largest polyp in the high rectum measuring $38 \times 37 \mathrm{~mm}$ was lobulated. Pathological results showed that the large polyp in the rectum is adenocarcinoma invading the smooth muscle layer; other polyps are typical Peutz-Jeghers polyps, with low-grade dysplasia. The patient was diagnosed with a moderately differentiated adenocarcinoma invading the smooth muscle layer/ Peutz-Jeghers syndrome.

Keywords: Peutz-Jeghers Syndrome, colorectal adenocarcinoma. 